\title{
Angiotensin II-mediated vascular smooth muscle cell growth signaling
}

\section{T. Inagami and S. Eguchi}

Department of Biochemistry, Vanderbilt U niversity, Nashville, TN, USA

\section{Correspondence \\ T. Inagami \\ Department of Biochemistry \\ Vanderbilt University \\ Nashville, TN 37232-0146 \\ USA \\ Fax: + 1-615-322-3201 \\ E-mail: \\ inagamit@ ctrvax.vanderbilt.edu \\ Presented at the III International Symposium on Vasoactive Peptides, Belo Horizonte, MG, Brasil, \\ October 8-10, 1999.}

Research supported by the National Institutes of Health, USA (grants HL58205 and HL35323).

Received November 26, 1999 Accepted February 11, 2000

\section{Abstract}

The mechanism by which Ang II stimulates the growth of vascular smooth muscle cells was investigated by measuring the phosphorylation of mitogen-activated protein kinases ERK 1 and ERK 2. $\mathrm{Ca}^{2+}$ ionophore was found to have effects practically analogous to Ang II. We found that the signaling pathway involves the activation of epidermal growth factor receptor (EGFR) kinase, activation of the adaptor proteins Shc and Grb2, and the small G-protein Ras. Although the mechanism of $\mathrm{AT}_{1}$ - $\left(\right.$ or $\left.\mathrm{Ca}^{2+}\right)$-induced activation of EGFR is not yet clear, we have found that calcium-dependent protein kinase $C A K ß$ / PYK2 and c-Src are involved in this process. These studies indicate a transactivation mechanism that utilizes EGFR as a bridge between a Gq-coupled receptor and activation of phosphotyrosine generation.
Key words

- Angiotensin II

- Type 1 receptor

- Epidermal growth factor receptor

- Vascular smooth muscle cells

\section{Introduction}

Heptahedral receptors have been considered to be coupled to various heterotrimeric G-proteins and transmit their signals through the classical 3',5'-cyclic adenosine mononucleotide (cAMP) by Gs or Gi, or by elevation of cytoplasmic $\mathrm{Ca}^{2+}$ or stimulation of protein kinase $\mathrm{C}(\mathrm{PKC})$ through the activation of $\mathrm{Gq}_{/ 11}$. On the other hand, signals regulating cellular growth have been considered to go through growth factor or cytokine receptors, which have a single transmembrane domain, like receptors for epidermal growth factor (EGFR) and platelet-derived growth factor (PDGFR). However, some of the heptahedral (heterotrimeric G-proteincoupled) receptors, such as the type 1 angiotensin II (Ang II) receptor, $\mathrm{AT}_{1}$, have been recognized to be one of the most potent stimulators of hypertrophic remodeling of the vascular and cardiac ventricular wall (15). The mechanism for such a growth stimulation by Ang II, other than the well-known vascular contraction, regulation of renal tubular electrolyte handling, aldosterone release and facilitation of adrenergic release, has not been clear.

However, in recent years observations of Ang II-stimulated activation of some of the mitogen-activated protein kinase (MAPK) such as extracellular signal-regulated kinase (ERK 1/2) have been reported, even though the pathway leading to ERK activation is, in many cases, mediated by protein tyrosine kinases and is thought to require the growth factor, or cytokine receptor signaling mechanisms since it seems to require tyrosine phosphorylation $(6,7)$.

As Ang II receptor subtypes were defined as subtype-specific non-peptidic receptors (8), the growth stimulation by Ang II was 
identified to reside in the type 1 receptor $\mathrm{AT}_{1}$. Following the cloning and structure determination of $\mathrm{AT}_{1}$, by us (9) and Murphy et al. (10), studies by Morrero et al. (11-13) and Dostal et al. (14) suggested possible direct binding of phospholipase C- $\gamma$ (PLC- $\gamma$ ) and Janus kinase (JAK) to a phosphotyrosyl residue in the carboxyterminal segment of $\mathrm{AT}_{1}$, possibly $\mathrm{Tyr}^{319}$ of $\mathrm{Tyr}^{319}$-Ile-ProPro- $^{322}$, and subsequent activation of these enzymes.

However, we entertained a different hypothesis since we found that the $\mathrm{C}$-terminus truncation of rat $\mathrm{AT}_{1}$ at residue $\mathrm{Lys}^{318}$ or eliminating the Tyr-Ile-Pro-Pro did not eliminate the activation of ERK. Another rationale for the hypothesis of the direct activation of the tyrosine kinase system by $\mathrm{Tyr}^{319}$ was due to the abundant presence of PLC- $\gamma$ and failure to observe PLC- $\beta$ in certain vascular smooth muscle cell (VSMC) lines which was consistently not the case in explanted VSMC we had used for a long time.

\section{Elevation of $\mathrm{Ca}^{2+}$ mimics Ang II in MAPK/ERK activation}

We hypothesized that the PLC- $\beta$-mediated increase in $\mathrm{Ca}^{2+}$ or PKC may be the mechanism of Ang II-mediated MAPK/ERK activation and demonstrated that calcium ionophore A23187 increased MAPK. Furthermore, the intracellular calcium chelator

Figure 1 - Effects of the intracellular $\mathrm{Ca}^{2+}$ chelator BAPTA-AM on Ang II-induced extracellular signal-regulated kinase/mitogenactivated protein kinase (ERK/ MAPK) activation. Cultured rat VSMC were pretreated with BAPTA-AM $(10 \mu \mathrm{M})$ for $30 \mathrm{~min}$, and then stimulated with Ang II $(100 \mathrm{nM})$ for $5 \mathrm{~min}$. The ERK/ MAPK activity toward a specific substrate was determined.

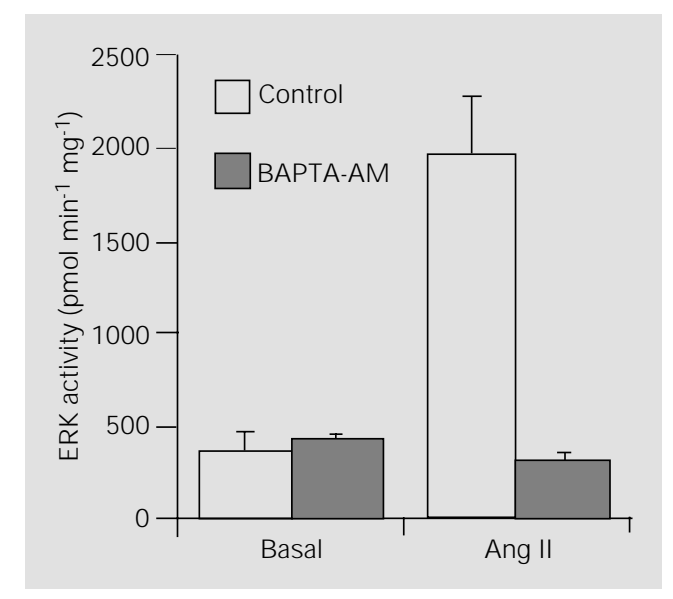

BAPTA-AM or calcium release inhibitor TMB8 abolished the MAPK activation by Ang II, as shown in Figure 1. Interestingly, similar patterns of regulation were also seen in the activation of the small G-protein Ras which is located upstream of ERK. Thus, we were able to show that the activation of ERK by intracellular calcium proceeds through the Ras-dependent pathway (15). The precise mechanism of activation of Ras or MAPK by $\mathrm{Ca}^{2+}$ is not known. The possibility of PKC-mediated signaling was eliminated for VSMC pretreated with a PKC inhibitor GF109203X or by PKC depletion by overnight exposure to phorbol ester. This is a unique and important feature of VSMC in contrast to cardiomyocytes in which a PKCmediated mechanism seems to be involved (16).

\section{Involvement of EGFR in the activation of Ras and MAPK}

However, the role of $\mathrm{Ca}^{2+}$ (but not PKC) in the activation of Ras and MAPK was not clear. To clarify the mechanism we examined steps upstream of Ras, which were most likely growth factor receptors.

As shown in Figure 2, activated EGFR transmits its signal by tyrosine phosphorylation of several tyrosine residues by EGFR kinase, subsequently forming a complex with Shc and then Grb2, or directly with Grb2. Grb2, in turn, activates the GDP-GTP exchange protein $\mathrm{mSOS}$ for Ras. This pathway was revealed by experiments using a fusion protein formed between glutathione-S-transferase (GST) and Grb2 for affinity precipitation of complex of Grb2 with Shc, EGFR and/or Sos.

By this technique we have demonstrated that activation of EGFR, as reflected by a complex formation with Grb2-GST, is induced by elevated cytoplasmic $\mathrm{Ca}^{2+}$, and the activated EGFR leads to the activation of MAPK/ERK (17). Interestingly, the transactivation of EGFR occurs by an intracellular 
mechanism rather than by EGF, which may have been produced and released from the Ang II-activated VSMC because the conditioned medium of Ang II-activated VSMC was not capable of activating EGFR in VSMC (17). This is a new concept of EGFR activation by an intracellular mechanism through a $\mathrm{Ca}^{2+}$-dependent system.

If EGFR mediates Ang II-dependent activation of ERK, it is tempting to examine if a similar but distinct PDGFR could function as a similar mediator. EGFR kinase and PDGFR kinase specific inhibitors tyrphostin AG1478 and AG1295, respectively, became available (18). The expected inhibition of the activation of ERK by Ang II was observed only with the EGFR kinase inhibitor AG1478 (75\% reduction), whereas the PDGFR kinase inhibitor AG1295 showed no significant effect (17). At present the mechanism for the selective activation of EGFR by Ang II but not PDGFR is not clear. However, it is interesting to note that the quantity of PDGFR in VSMC is much greater than that of EGFR. For understanding the mechanism of the specific activation of EGFR, a major void in our knowledge exists for the mechanism between increased cytoplasmic $\mathrm{Ca}^{2+}$ and EGFR activation. However, it is important to recognize that Gprotein-coupled receptors are capable of transactivating a receptor tyrosine kinase system in many cells (19-21). This new concept is now supported by a similar mechanism mediated by a variety of heptahedral receptors.

\section{Calcium-activated tyrosine kinase}

Recently, several investigators reported a new $\mathrm{Ca}^{2+}$-activated tyrosine kinase in the cytoplasmic fraction, which was named CAKß (22)/PYK2 (23)/RAFTK (24)/ CADTK (25). Although the structure of this kinase indicates that it belongs to the family of focal adhesion kinase (FAK), this $\mathrm{Ca}^{2+}$ activated proline-rich tyrosine kinase was different from FAK.

The CAKß/PYK2 type soluble tyrosine kinase is a good candidate to mediate the signal of an elevated cytoplasmic $\mathrm{Ca}^{2+}$ to EGFR and/or ERK 1/2. We and others were able to show that such a mechanism is activated by Ang II or $\mathrm{Ca}^{2+}$ in $\operatorname{VSMC}(26,27)$, liver epithelial cells (25), cardiac fibroblasts (28), and pheochromocytoma cells (23). The cytoplasmic tyrosine kinase was activated by Ang II through $\mathrm{AT}_{1}$ or the $\mathrm{Ca}^{2+}$ ionophore A23187, but not by PKC (26).

Interestingly, a member of an oncogene and a soluble protein tyrosine kinase, c-Src, is also activated in this process of Ang II $\left(\mathrm{AT}_{1}\right)$-stimulated transactivation of EGFR, as detected by the monoclonal antibody P28 specific for the active form of c-Src (17). The activation of PYK2 and c-Src precedes the transactivation of EGFR, since the inhibition of the EGFR kinase by tyrphostin AG1478 does not affect the activation of PYK2 or c-Src (26). Active c-Src and PYK2 also form a coprecipitable complex in agreement with the observation of Dikic et al. (29) in a neuronal cell system. This system is very complex and we are not yet able to describe it as a linear vertical flow of signaling events. This mechanism involving at least three kinases seems to be much more complex than we have imagined. It is possible that this area may also involve mechanisms and systems

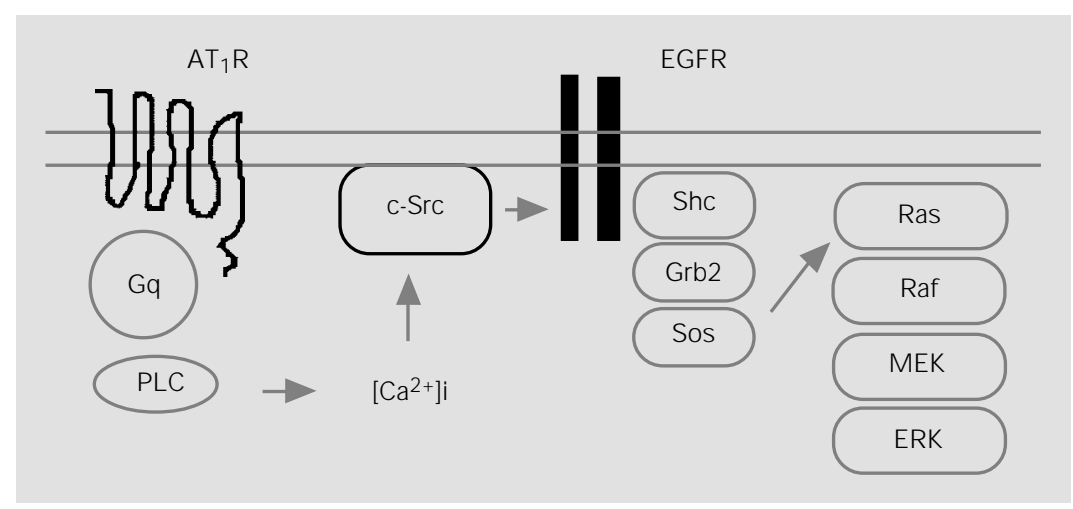

Figure 2 - In VSMC, $\mathrm{Ca}^{2+}$-dependent transactivation of epidermal growth factor receptor (EGFR) mediates Ang II-induced Ras/ERK MAPK activation. AT $T_{1}$, Type 1 angiotensin II receptor; PLC, phospholipase C; ERK, extracellular signal-regulated kinase; MEK, MAPK kinase. 
that may be stimulated by reactive oxygen species.

\section{Roles of activated ERKs in VSMC}

ERKs are a focal point for diverse cell growth and proliferating responses. Activation of ERK induces the transcription of the fos gene. Indeed, we were able to directly demonstrate c-Fos expression in a rapid response to Ang II-induced EGFR transactivation and subsequent ERK activation. Ang II-

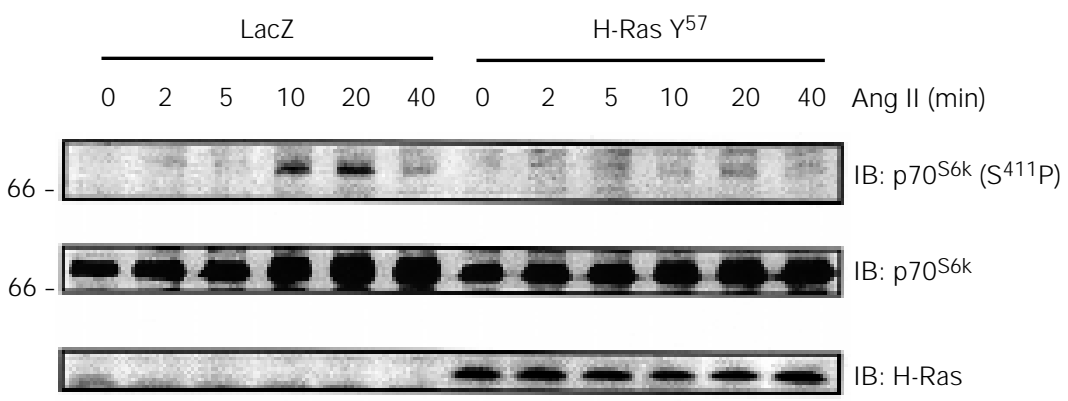

Figure 3 - Effect of dominant-negative H-Ras transfection of angiotensin II (Ang II)-induced Ser ${ }^{411}$ phosphorylation $\left(S^{411} \mathrm{P}\right)$ of $\mathrm{p} 70^{\mathrm{S} 6 \mathrm{k}}$. VSMC were transfected with AdRas $\mathrm{Y}^{57}$ or control AdLacZ as indicated before stimulation. Cells were stimulated with Ang II (100 nM) for indicated durations. Cell lysates were analyzed by immunoblotting (IB) with anti[phospho-Ser ${ }^{411}$ ]-p70 $56 \mathrm{k}$, anti-p70 $56 \mathrm{k}$, and anti-H-Ras antibodies as indicated by repeated reprobing.

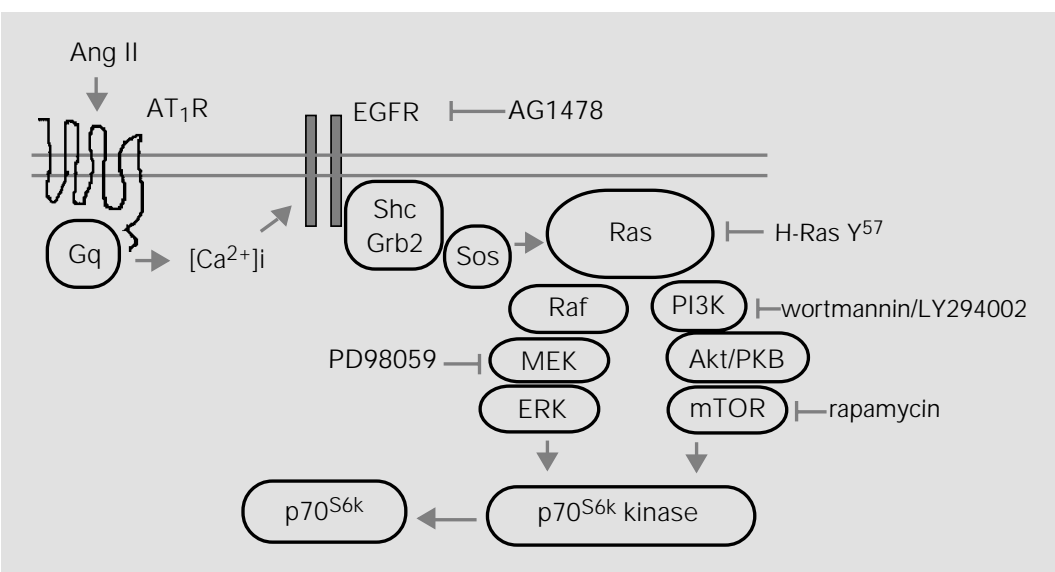

Figure 4 - Hypothetical pathways involved in the phosphorylation of $p 70^{56 \mathrm{k}}$ by angiotensin II (Ang II). According to this model, activation of the putative S6 kinase (S6k) by Ang II requires two separate pathways which bifurcate at the point of Ras activation through transactivated epidermal growth factor receptor (EGFR). $\mathrm{AT}_{1} \mathrm{R}$, Type 1 Ang II receptor; ERK, extracellular signal-regulated kinase; PKB, protein kinase B; PI3K, phosphatidyl inositol-3-kinase; MEK, MAPK kinase. induced protein synthesis is also mediated by the EGFR and ERK (30).

\section{Dual signals for S6 kinase activation}

In the hypertrophic responses of VSMC, the net effects of multiple effectors such as Ang II, insulin, etc., are syntheses of two discrete S6 kinases (p90 and p70 S6 kinases), which regulate the function of ribosomes. $\mathrm{p} 90^{\mathrm{S} 6 \mathrm{k}}$ is subject to direct activation by ERK, but the upstream of $\mathrm{p} 70^{\mathrm{s} 6 \mathrm{k}}$ still remains unclear.

Quite recently, we found that regulation of $\mathrm{p} 70^{\mathrm{S} 6 \mathrm{k}}$ is complex, since it is activated by Ang II through two separate but related signaling pathways (31), as discussed below. We have shown that Ras-dependent ERK activation results in the activation of p70 ${ }^{\mathrm{s} 6 \mathrm{k}}$. A dominant negative mutant of Ras was found to inhibit not only ERK $1 / 2$, but also $\mathrm{p} 70^{\mathrm{S} 6 \mathrm{k}}$ (Figure 3). Inhibition of MEK (MAPK kinase) by PD98059 (the ERK pathway on the left side below Ras in Figure 4) was sufficient to block p $70^{\mathrm{s} 6 \mathrm{k}}$, whereas phosphatidyl inositol-3-kinase (PI3K) inhibitor blocked the $\mathrm{p} 70^{\mathrm{S} 6 \mathrm{k}}$ activation without affecting the ERK. This observation suggested the presence of a second pathway. Indeed, we observed that Ang II activates Akt/protein kinase $\mathrm{B}$ (PKB). Akt/PKB was known to be activated by insulin through the activation of PI3K (32). However, we have found that Ang II activates wortmannin/LY294002-sensitive PI3K and its downstream components Akt/PKB and $\mathrm{p} 70^{\mathrm{S} 6 \mathrm{k}}$ by phosphorylating the Ser ${ }^{411}$ residue of the latter, shown on the right side of Figure 4.

Activation of this pathway by insulin does not activate ERK. Of particular interest is that the PI3K-activating insulin effect shares a common signaling pathway with Ang II. The role of Ras is also intriguing in that it activates two bifurcating pathways. Although, Akt/PKB is a multifunctional activator of various signaling pathways, its activation of $\mathrm{p} 70^{\mathrm{s} 6 \mathrm{k}}$ results 
in resynthesis of the pathways leading to the hypertrophy of vascular smooth muscle cells (Figure 4).

\section{Conclusion}

We tried to summarize recent findings from our laboratory and others focusing on the hypertrophic effects of Ang II mediated by $\mathrm{p} 70^{\mathrm{S} 6 \mathrm{k}}$ in quiescent cultured vascular smooth muscle cells. Although there are some large gaps in our knowledge, we have provided unequivocal evidence of transactivation of EGFR by a $\mathrm{Gq}_{/ 11^{1}}$-coupled receptor in a unique fashion since PDGFR is not activated.

Some of the components of pivotal importance in this system are Src family tyrosine kinase, EGFR, Ras-ERK, or Ras-PI3K and $A k t$, ending at $\mathrm{p} 70^{\mathrm{S} 6 \mathrm{k}}$. CAKß/PYK2 may be a potential candidate for bridging $\mathrm{Ca}^{2+}$ to EGFR.

These studies are of particular relevance to vascular remodeling since this system seems to provide possible common sites of actions of two major components of vascular degenerative change, insulin and Ang II. Furthermore, it is important to note that the Ang-II-to-ERK pathway is mediated by reactive oxygen species (Frank GD, Eguchi S, Yamakawa $\mathrm{T}$, Tanaka $\mathrm{S}$, Inagami $\mathrm{T}$ and Motley ED, unpublished results).

\section{Acknowledgments}

We are indebted to Drs. Kotaro Numaguchi, Hiroaki Iwasaki, Yukio Hirata, Gerald D. Frank, and Evangeline D. Motley for valuable scientific input, and to Tina Stack for preparation of the manuscript.

\section{References}

1. Geisterfer AA, Peach MJ \& Owens GK (1988). Angiotensin II induces hypertrophy, not hyperplasia, of cultured rat aortic smooth muscle cells. Circulation Research, 62: 749-756.

2. Gibbons GH, Pratt RE \& Dzau VJ (1992). Vascular smooth muscle cell hypertrophy vs hyperplasia of cultured rat aortic smooth muscle cells. J ournal of Clinical Investigation, 90: 456-461.

3. Weber H, Taylor DS \& Molloy CJ (1994). Angiotensin II induces delayed mitogenesis and cellular proliferation in rat aortic smooth muscle cells: correlation with the expression of specific endogenous growth factors and reversal by suramin. J ournal of Clinical Investigation, 93: 788798.

4. SadoshimaJ \& Izumo S (1993). Molecular characterization of angiotensin II-induced hypertrophy of cardiac myocytes and hyperplasia of cardiac fibroblasts; critical role of the $A T_{1}$ receptor subtype. Circulation Research, 73: 413-423.

5. Schorb W, Booz GW, Dostal DE, Conrad KM , Chang KC \& Baker KM (1993). Angiotensin II is mitogenic in neonatal rat cardiac fibroblast. Circulation Research, 72: 1245-1254.

6. Griendling $\mathrm{KK}$, Ushio FM, Lassegue B \& Alexander RW (1997). Angiotensin II sig- naling in vascular smooth muscle: new concepts. Hypertension, 29: 366-373.

7. Berk BC \& Corson MA (1997). Angiotensin II signal transduction in vascular smooth muscle: role of tyrosine kinases. Circulation Research, 80: 607-626.

8. Timmermans PBMWM, Wong PC, Chiu AT, Herblin WF, Benefield $P$, Carini $D J$, Lee RJ , Wexler RR, Saye J AM \& Smith RD (1993). Angiotensin II receptors and angiotensin II receptor antagonist. Pharmacological Reviews, 45: 205-251.

9. Sasaki K, Yamano $Y$, Bardhan S, Iwai N, Murray J J , Hassegawa M, Matsuda Y \& Inagami T (1991). Cloning and expression of a complementary DNA encoding a bovine adrenal angiotensin II type-1 receptor. Nature, 351: 230-233

10. Murphy TJ , Alexander RW, Griendling KK, Runge MS \& Bernstein KE (1991). Isolation of a cDNA encoding the vascular type1 angiotensin II receptor. Nature, 351: 233-236.

11. Morrero MB, Schieffer B, Paxton WG, Heerdt L, Berk BC, Delafontaine P \& Bernstein KE (1995). Direct stimulation of J ak/STAT pathway by the angiotensin II $\mathrm{AT}_{1}$ receptor. Nature, 375: 247-255.

12. Ali SM, Sayeski PP, Dirksen LB, Hayzer DJ , Morrero MB \& Bernstein KE (1997). Dependence on the motif YIPP for the physical association of J ak 2 kinase with the intracellular carboxyl tail of the angiotensin II $A T_{1}$ receptor. J ournal of Biological Chemistry, 272: 23382-23388.

13. Venema RC, J u H, Venema VJ , Schieffer B, Harp J B, Ling BN, Eaton DC \& Morrero M (1998). Angiotensin Il-induced association of phospholipase $C \gamma 1$ with the Gprotein-coupled $A T_{1}$ receptor. J ournal of Biological Chemistry, 273: 7703-7708.

14. Dostal DE, Hunt RA, Kule CE, Bhat GJ Karoor V, McWhinney CD \& Baker KM (1997). Molecular mechanisms of angiotensin II in modulating cardiac function: intracardiac effects and signal transduction pathways. J ournal of Molecular and Cellular Cardiology, 29: 2893-2902.

15. Eguchi S, Matsumoto T, Motley ED, Utsunomiya H \& Inagami T (1996). Identification of an essential signaling cascade for mitogen-activated protein kinase activation by angiotensin II in cultured rat vascular smooth muscle cells: possible requirement of Gq-mediated p21 ras activation coupled to a $\mathrm{Ca}^{2+} /$ calmodulin sensitive tyrosine kinase. J ournal of Biological Chemistry, 271: 14169-14175.

16. Zhou Y, Komuro I, Yamazaki T, Kudoh S, Aikawa R, Zhu W, Shiojima I, Hiroi Y, Tobe K, Kadowaki T \& Yazaki Y (1998). Cell type specific angiotensin II-evoked signal trans- 
duction pathways. Circulation Research, 82: 337-345.

17. Eguchi $\mathrm{S}$, Numaguchi $\mathrm{K}$, Iwasaki $\mathrm{H}$, Matsumoto T, Yamakawa T, Utsunomiya $\mathrm{H}$, Motley ED, Kawakatsu H, Owada KN, Hirata Y, Murumo F \& Inagami T (1998). Calcium-dependent epidermal growth factor receptor transactivation mediates the angiotensin II-induced mitogen-activated protein kinase activation in vascular smooth muscle cells. J ournal of Biological Chemistry, 273: 8890-8896.

18. Levitzki A \& Gazit A (1995). Tyrosine kinase inhibition: an approach to drug development. Science, 267: 1782-1788.

19. Zwick E, Hackel $P O$, Norbert $P \&$ Ullich $A$ (1999). The EGF receptor as central transducer of heterologous signaling systems. Trends in Pharmacological Sciences, 20: 408-412.

20. Carpenter $G$ (1999). Employment of the epidermal growth factor receptor in growth factor-independent signaling pathways. J ournal of Cell Biology, 146: 697702.

21. Luttrell LM, Kaaka $Y \& \&$ Lefkowitz RJ (1999). Regulation of tyrosine kinase cascades by G-protein-coupled receptors. Current Opinion in Cell Biology, 11: 177183.

22. Sasaki $H$, Nagura K, Ishino $M$, Tobioka $H$, Kotani K \& Sasaki T (1995). Cloning and characterization of cell adhesion kinase $B$, a novel protein-tyrosine kinase of the fo- cal adhesion kinase subfamily. J ournal of Biological Chemistry, 270: 21206-21219.

23. Lev $\mathrm{S}$, Moreno $\mathrm{H}$, Martinez R, Canoll $\mathrm{P}$, Peles E, Mussacchio J M, Plowman GD, Rudy B \& Schlessinger J (1995). Protein tyrosine kinase PYK2 involved in $\mathrm{Ca}^{2+}$ induced regulation of ion channel and MAP kinase functions. Nature, 376: 737745.

24. Avaham $\mathrm{S}$, London $\mathrm{R}, \mathrm{Fu} \mathrm{Y}$, Ota $\mathrm{S}$, Hiregowdara D, Li J , J iang S, Pasztor LM, White RA, Groopman JE \& Avaham H (1995). Identification and characterization of a novel related adhesion focal tyrosine kinase (RAFTK) from megakaryocytes and brain. J ournal of Biological Chemistry, 270: 27742-27751.

25. Yu H, Li X, Marchetto GS, By R, Hunter D, Calvo B, Dawson TL, Wilm M, Anderegg RJ , Graves LM \& Earp HS (1996). Activation of a novel calcium-dependent protein-tyrosine kinase: correlation with c-J un $\mathrm{N}$-terminal kinase but not mitogen activated protein kinase activation. J ournal of Biological Chemistry, 271: 29993-29998.

26. Eguchi S, Iwasaki H, Inagami T, Numaguchi K, Yamakawa T, Motley ED, Owada KM, Marumo F \& Hirata Y (1999). Involvement of PYK2 in angiotensin II signaling of vascular smooth muscle cells. Hypertension, 33 (Part II): 201-206.

27. Brinson $A E$, Harding $T$, Diliberto $P A, H e Y$, Li X, Hunter D, Herman B, Earp HS \& Graves LM (1998). Regulation of a cal- cium-dependent tyrosine kinase in vascular smooth muscle cells by angiotensin II and platelet-derived growth factor: dependence on calcium and the actin cytoskeleton. J ournal of Biological Chemistry, 273: 1711-1718.

28. Murasawa $S$, Mori $Y$, Nozawa $Y$, Masaki $\mathrm{H}, \mathrm{M}$ aruyama $\mathrm{K}$, Tustsumi $\mathrm{Y}$, M origuchi $\mathrm{Y}$, Shibasaki Y, Tanaka Y, Iwasaka T, Inada M \& Matsubara H (1998). Role of calciumsensitive tyrosine kinase PYK2/CAKß/ RAFTK in angiotensin II-induced Ras/ERK signaling. Hypertension, 32: 668-675.

29. Dikic I, Tokiwa G, Lev S, Courteneige SA \& Schlessinger J (1996). A role for Pyk 2 and Src in linking G-protein-coupled receptors with MAP kinase activation. Nature, 383: 547-550.

30. Eguchi S, Iwasaki H, Hirata Y, Frank GD, Motley ED, Yamakawa T, Numaguchi K \& Inagami T (1999). Epidermal growth factor receptor is indispensable for c-Fos expression and protein synthesis by angiotensin II. European J ournal of Pharmacology, 376: 203-206.

31. Eguchi S, Iwasaki H, Ueno H, Frank GD, Motley ED, Eguchi K, Marumo F, Hirata Y \& Inagami T (2000). Possible requirement of EGF receptor, RAS, ERK and AKT. J ournal of Biological Chemistry (in press).

32. Alessi DR \& Cohen P (1998). Mechanism of activation and function of protein kinase B. Current Opinion in Genetics and Development, 8: 55-62. 